Tips om medisinsk litteratur, andre bøker, filmer og elektroniske medier som bør anmeldes, sendes tidsskriftet@legeforeningen.no

\section{Noe å lære av}

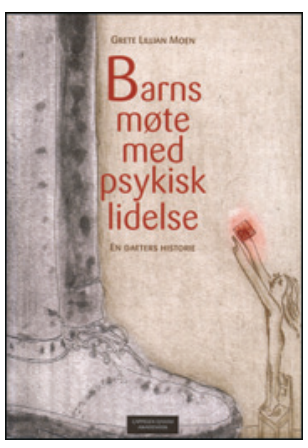

Grete Lillian Moen

\section{Barns møte med psykisk lidelse}

En datters historie. 2. utg. 157 s, ill.

Oslo: Cappelen Damm Akademisk, 2012

Pris NOK 298

ISBN 978-82-02-35750-4

1. januar 2010 kom lovendringer som skal sikre at avdelinger både innen somatisk medisin, psykisk helsevern og rusomsorg skal ha egne barneansvarlige med særskilt ansvar for pasientenes barn. Dermed er blant annet 18-årsgrensen for hvem som kan regnes som pårørende endret, men å få dette til å fungere vil åpenbart ta tid. I en travel hverdag er det lett å glemme at pasienten har barn, og mange ansatte føler seg dessuten usikre på hvordan de best kan møte dem.

Forfatterens mor fikk en fødselsdepresjon og en alvorlig psykisk lidelse etter hennes fødsel. Med denne boken ønsker hun å bidra til en bedre praksis. Forfatteren er utdannet barnevernspedagog og har mange års erfaring fra arbeid innen barnevern og psykiatri. Ved kurs og foredrag om temaet har hun også fått mange tilbakemeldinger fra pårørende. På en realistisk og lite fordømmende måte forteller hun om sine egne og andres reaksjoner, skyldfølelse, skam og utilstrekkelighet. De fire kapitlene inneholder også små dikt og dagboknotater som utdyper fremstillingen. Her er noen skremmende, men også aktuelle eksempler på manglende engasjement i mottak og på avdelingsnivå. Boken har også korte etterord av hennes tre søsken. Dette bidrar til et familieperspektiv på utfordringene innen dette feltet, hvor det fortsatt er viktige forbedringspotensialer.

Fremstillingen bygger på begrensede litteraturreferanser. Disse består for det meste av tidlige utgaver av fagbøker for helsearbeidere og innlegg i dagspressen fra fagfolk. Siden temaet er relevant for både lærere, helsearbeidere og studenter ville det vært nyttig med litt mer kunnskapsbasert informasjon, blant annet om ulike former for fødselsdepresjoner og forløp over tid. Slik det her fremstilles, kan leseren lett få en utilsiktet og kanskje negativ oppfatning av prognosen.

Omslagstegningen av et lite barn som strekker seg mot en stor støvel er talende i seg selv, men hvorfor den er trykt ytterligere fire ganger, er uvisst. Det kan gi et mer pessimistisk inntrykk av muligheter for endring enn det forfatteren gir uttrykk for når hun konkluderer med at «i møte med dyktige og kloke mennesker har jeg lært at negative livshistorier ikke er permanente (...) Jeg velger selv hvordan min historie skal være, skal prege meg og mitt liv fremover». Nettopp derfor tror jeg denne boken kan gi leserne, enten de er studenter eller profesjonelle helsearbeidere, økt forståelse av et utfordrende tema. Her kan blant annet enkle historier tjene til skrekk og advarsel, øke motivasjonen for å lære og for å forstå mer, og dermed bidra til å forebygge at barn av somatisk eller psykisk syke foreldre selv utvikler symptomer eller dysfunksjon.

\section{Kort og godt om hiv for helsepersonell}

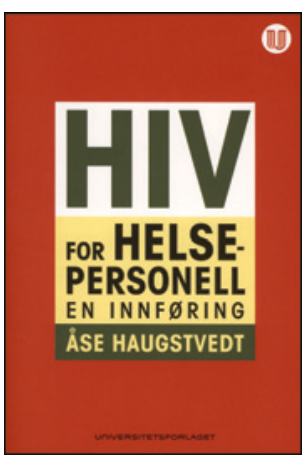

\author{
Åse Haugstvedt \\ HIV for helsepersonell
}

En innføring. $140 \mathrm{~s}$, tab, ill. Oslo:

Universitetsforlaget, 2012. Pris NOK 249

ISBN 978-82-15-01960-4

Åse Haugstvedt er spesialist i hud- og kjønnssykdommer ved Olafiaklinikken i Oslo, en lavterskel «drop-in» poliklinikk for diagnostisering og behandling av seksuelt overførbare infeksjoner. Her diagnostiserer man om lag 30 nye pasienter med hiv per år. Med bakgrunn i hennes egne og pasienters erfaringer med manglende kunnskap blant helsepersonell har hun nå skrevet en kortfattet bok om hiv. Målgruppen er personell i helsesektoren som ikke har anledning å bli kjent med hiv i sitt daglige virke, men som allikevel trenger et minimum av kunnskap for både å opptre profesjonelt og ta de riktige avgjørelsene når det en sjelden gang blir aktuelt. Det blir som å ha lest beredskapsplanen før katastrofen.

Åse Haugstvedt har bygd opp boken omkring fem autentiske, men anonymiserte pasientfortellinger som alle illustrerer forskjellige aspekter av å bli diagnostisert og leve med hiv. Innflettet mellom disse fortellingene får hun i kortfattet og enkel språkdrakt gjort rede for det viktigste om hiv-viruset, hiv-historikken og epidemiologien i Norge og den aktuelle måten å diagnostisere og behandle hiv på. Det er uttrykkelig sagt at boken ikke er for spesialister i feltet, men for de øvrige i helsetjenesten som tross alt bør vite litt mer enn hva de har hørt i nyhetene. Fortellingene gir en fordypet innsikt $\mathrm{i}$ hvordan det er å få diagnosen og leve med den og illustrerer også hvordan pasienter med hiv blir møtt i helsetjenesten.

Etter å ha lest de åtte korte kapitlene, hvorav det ene er en liste med aktuelle nettsteder - og muligens brukt referanselisten, ordlisten og registeret - vil leseren være godt utstyrt for å møte sin første pasient som spør om han burde teste seg for hiv. En viktig bok for hele Helse-Norge - før det skjer.

\section{Thorkild Tylleskär}

Senter for internasjonal helse

Universitetet i Bergen 